\section{NOTIFICATION OF JUVENILE SUFFERERS FROM VENEREAL DISEASE.}

To the Editor of THE LANCET.

SIr,- The entire lack of provision for the treatment of venereal disease occurring amongst natives in Durban has rendered it necessary to return them to their kraals, often in a highly infectious condition. It is probable that a large number of these recover without treatment of any kind, but there is always the danger that they may be instrumental in the spread of venereal diseases in outlying districts, especially when the obvious signs of their condition become less evident to themselves and their friends. Although this danger has been recognised by the Grovernment, no suitable provision has so far been made, and the problem was aggravated when, in December, 1921, the Government hospital refused to treat any cases of venereal disease occurring amongst even Europeans who were resident in the borough. The matter has recently been taken up by the Juvenile Affairs Department who approached the Minister for Public Health, urging that facilities for early treatment should be afforded to all sufferers in the interests of juveniles, and, further, that venereal disease occurring amongst juveniles up to the age of 18 years should be notifiable to the medical officer of health for the borough. Although due consideration had been given to the reasons that had been advanced against the notification of venereal disease occurring amongst adults, it was felt that juveniles were unlikely to realise the seriousness of the disease so far as they were concerned, and that, in the interests of the young patient, his relations, and those who occupied the same dwelling-house, the necessary treatment should be undertaken in a suitable ward at the earliest possible moment after the condition had been diagnosed. This step may well meet with the approval of others who are interested in this aspect of disease prevention.-I am, Sir, yours faithfully,

Durban, Oct. 24th, 1922. F. G. Cawston, M.D. Camb.

\section{GASTRO-ENTEROSTOMY CLAMPS.}

\section{To the Editor of THE LANCET.}

SIR,- Surgeons who use clamps in gastroenterostomy will be interested in the suggested improvement in their design described by Mr. Norman M. Dott in your issue of Sept. 23rd. In a well-illustrated paper, which appeared in Surgery, Gynecology, and Obstetrics, August, 1916, vol. xxiii., p. 225, Dr. Joseph Eastman described a clamp on exactly the same principle under the title of "An Uncomplicated and Convenient Intestinal Anastomosis Clamp." In Mr. Dott's design, no doubt arrived at independently, the absence of the short handle, the separation of each element, and the bullet-shaped nut instead of a heart-shaped nut, appear to be improvements on Dr. Eastman's clamp.

I am, Sir, yours faithfully,

Ian Macdonald, M.D.

Huelva, Spain, Nov. 10th, 1922.

\section{NIGHT SWEATS.}

To the Editor of THE LANCET.

Srr,-My friend, Dr. F. R. Walters, in his letter to THE LANCET of August 12th suggests that I was ambiguous as to the use of slumber mats. I think my reference to the "Shibboleths of Tuberculosis" made it quite plain that $I$ only recommended these mats after hygienic means had failed to prevent the sweats; he also suggests that my experience is abnormal. $\mathrm{He}$ goes on to say that " one ought to regard "night" sweats as presumptive evidence of insufficient ventilation or other hygienic blunder." As I had distinctly stated we had severe night sweats here, there would be no ambiguity in my taking this statement as a very severe reflection on the administration of Colindale.
I think, however, each of his points is answered by the following letter published in the British Medical Journal of Oct. 21st last (p. 780):-

"I rishman" asks for advice in the treatment of very profuse sweating in a case of pulmonary tuberculosis; the patient is 32 ; the area of lung involved is quite moderate, as also are the evening temporature and the amount of sputum; the the evening temperature and the amount of sputum; the
hygienic conditions are superb and two nurses are in attendance; the routine remedies are futile....

Here is the early case-to which type I referredsweating in spite of the best possible conditions and therefore eminently suitable for a slumber mat. I am, Sir, yours faithfully, Marcus Paterson.

Colindale Hospital, Hendon, Nor. 13th, 1922

\section{AUENBRUGGER'S BICENTENARY.}

To the Editor of THE LANCET.

SIR, - I think that it has escaped general attention that this year marks the bicentenary of the birth of the discoverer of the first important step in the clinical examination of the chest-namely, the method of percussion. This advance was made by Auenbrugger. The following extract from my grandfather's (Dr. Thomas Davies) lectures on "The Diseases of the Lungs and Heart," delivered at the London Hospital, and published in the Medical Gazette in 1835, states " that Leopold Auenbrugger was born at Graets in Styria in 1722- - he became physician to the Imperial Hospital of the Spanish Nation at Vienna. There it was that he prosecuted, as he expressed it, his studies inter taedia et labores on the subject for a period of seven years, and in the year 1763 he published a work which he called 'Inventum Novum ex Percussione Thoracis humani ut signo, abtrusis interni pectoris morbo detegendi.' No notice was taken of his book until 1770, when Rozière de la Chassaque, of Montpellier, translated it, avowing he knew nothing of the subject practically, and the inference he would lead you to draw is that he did not think much of the discovery himself.

"The pamphlet seemed now consigned to oblivion. However, Stoll, Van Swieten, and Cullen in his 'First Lines' make some mention of it, but declared they knew nothing of it practically. Corvisart, when preparing his celebrated clinical lectures, first met with the subject on reading Stoll's work. He immediately commenced a series of experiments, which he continued for 20 years, and in 1808 published a new translation of Auenbrugger with his own commentaries, a work that has been translated into every European language."

It seems to me to be fitting and worthy of interest to recall these historic facts.

I am, Sir, yours faithfully, ARThuR T. DAvies, M.D., F.R.C.P.

Tokenhouse Yard, E.C., Nov 11th, 1922.

\section{THE MENSTRUAL CYCLE AND CALCIUY CONTENT OF THE BLOOD.}

To the Editor of THE LANCET.

SIR,--Miss Widdows, B.Sc., in THe LANCET of Nov. 11th, p. 1037, states that the increase in the calcium content of the blood during menstruation " might be expected." Why during? Is it not more reasonably expected just antecedent to the period? May I also ask why Miss Widdows chooses the time midway to contrast with the menstrual time? Is she not aware of what is called on the Continent the Mittelschmerz? By choosing the time midway between the periods to contrast with the periods she chooses the one time in the cycle which is not a contrast, but is comparable. A realisation of the significance of the chart published some years ago in "Married Love" would have saved this confusion.

I am, Sir, yours faithfully, MARIE C. STOPES. 